\title{
KEABSAHAN PEMBERIAN BARCODE PADA MINUTA AKTA DAN SALINAN AKTA NOTARIS
}

\author{
Huddhan Ary Karuniawan \\ Magister Kenotariatan Universitas Narotama Surabaya \\ Email : huddhan.ary2018@gmail.com \\ I.A. Budhivaya \\ Magister Kenotariatan Universitas Narotama Surabaya \\ Email : 1a.budhivaya@gmail.com
}

\begin{abstract}
ABSTRAK
Terjadinya permasalahan yang berkaitan dengan jabatan Notaris pada saat ini banyak terjadi karena keaslian dari akta yang telah dibuat oleh atau dihadapan Notaris dipertanyakan. Kondisi tersebut melahirkan wacana mengenai penggunaan barcode dalam akta Notaris sebagai sarana pengaman untuk mengetahui keaslian produk Notaris tersebut.

Penulis dalam penelitian ini ingin menelaah dan menganalisa lebih lanjut tentang kedudukan isi barcode yang dilekatkan pada minuta akta dan salinan akta dan implikasi hukum terhadap minuta akta dan salinan akta notaris yg diberikan barcode.

Metode penelitian yang digunakan adalah penelitian hukum normatif, yaitu penelitian hukum yang dilakukan dengan cara meneliti bahan pustaka atau bahan hukum sekunder sedangkan pendekatan masalah dilakukan dengan menggunakan pendekatan undang-undang dan pendekatan konseptual.

Hasil penelitian menunjukkan bahwa barcode yang dilekatkan pada minuta dan salinan akta dapat berfungsi sebagai pengaman keaslian akta. Penggunaan barcode dalam minuta dan salinan akta harus tetap memperhatikan aspek kerahasiaan akta Notaris. Akta Notaris yang diberi barcode memiliki nilai pembuktian sebagai akta otentik selama aspek formal pembuatan akta yang telah ditentukan dalam Undang-Undang Jabatan Notaris terpenuhi.
\end{abstract}

Kata Kunci : Barcode, Akta Otentik, Notaris

\begin{abstract}
Authenticity becomes major issue nowadays since numerous scholars are questioning about justification of authentic notarial deed. This condition stimulates opinion to utilize barcode within the notarial deed in order to secure coupled with validate the authenticity of notarial deed.

The present study tries to elaborate and examine about legal position of barcode within notarial deed. Moreover, the present study also tries to elaborate further legal implication of barcode within the notarial deed.

The method used in the present study is a normative legal research, namely legal research which is conducted by examining the library materials or secondary law while in finding and collecting the data is done by two approaches, namely the law and conceptual approaches.

The present study concludes that utilization of barcode within notarial deed can be functioned as authenticity warrant of notarial deed. Furthermore, utilization of barcode


within notarial deed also needs to consider the confidentiality aspect of the notarial deed. Utilization of barcode within notarial deed can be used to justify authenticity of notarial deed as long it follows legal procedures of notarial deed publication under the legal constitution.

Keywords: Barcode, Authentic Notarial Deed, Notary Public

\section{Pendahuluan}

Perkembangan kehidupan bermasyarakat telah meningkatkan intensitas dan kompleksitas hubungan hukum yang harus mendapatkan perlindungan dan kepastian berdasarkan alat bukti yang menentukan dengan jelas hak dan kewajiban setiap subjek hukum. Oleh karena itu, agar terdapat perlindungan, kepastian, dan ketertiban, harus terdapat kegiatan pengadministrasian hukum (law administrating) yang tepat dan tertib (Neriana, 2015:2). Hal ini juga diperlukan untuk menghindari terjadinya hubungan hukum yang cacat dan dapat merugikan subjek hukum maupun masyarakat.

Kebutuhan akan suatu alat bukti adalah untuk membuktikan suatu hak yang dimiliki. Dalam hukum pembuktian, yang disebut dengan membuktikan berarti meyakinkan hakim tentang kebenaran dalil atau dalil-dalil yang dikemukakan dalam suatu persengkataan (R. Subekti, 2001:1). Menurut Darwan Prinst, yang dimaksud dengan pembuktian adalah pembuktian bahwa benar suatu peristiwa pidana telah terjadi dan terdakwa yang bersalah melakukannya, sehingga harus mempertanggungjawabkannya (Darwan Prinst, 1998:133). Sedangkan menurut Sudikno Mertokusumo : "pembuktian secara juridis tidak lain merupakan pembuktian secara historis. Pembuktian yang bersifat juridis ini mencoba menetapkan apa yang telah terjadi secara konkret. Baik dalam pembuktian secara juridis maupun ilmiah, maka membuktikan pada hakikatnya berarti mempertimbangkan secara logis mengapa peristiwa-peristiwa tertentu dianggap benar" (Sudikno Mertokusumo, 1999:109).

Dalam hal pembuktian dibutuhkan adanya suatu alat bukti. Alat-alat bukti secara keseluruhan diatur dalam Pasal 164 Herzien Inlandsch Reglement (HIR), yang menyatakan bahwa yang disebut bukti yaitu bukti surat, bukti saksi, sangka, pengakuan, sumpah. Sumber bukti lainnya antara lain keterangan ahli, hasil pemeriksaan setempat dan hal-hal yang tidak dibantah dan diakui kebenarannya oleh kedua belah pihak.

Ketentuan dalam Pasal 1867 Burgerlijk Wetboek (BW) menyatakan bahwa pembuktian dengan tulisan dilakukan dengan tulisan-tulisan otentik maupun dengan tulisan-tulisan di bawah tangan. Alat bukti yang berupa surat merupakan alat bukti tertulis. Untuk alat bukti yang berupa surat ini terbagi atas surat yang merupakan akta dan suratsurat lainnya yang bukan akta (Ibid:143). Dalam Pasal 1869 BW dinyatakan bahwa suatu surat dapat disebut akta apabila ditandatangani, tandatangan ini dapat berfungsi untuk membedakan akta yang satu dengan akta yang lain. Akta menurut bentuknya masih dibedakan lagi menjadi akta otentik dan akta di bawah tangan.

Apa yang dimaksud dengan akta otentik sendiri telah tertuang dalam Pasal 1868 BW yang menyebutkan : "Suatu akta otentik ialah akta yang didalam bentuk yang ditentukan oleh Undang-Undang, dibuat oleh atau dihadapan pegawai pegawai umum yang 
berwenang untuk itu di tempat dimana akta itu dibuat."

Akta otentik sebagai alat bukti terkuat dan terpenuh mempunyai peranan penting dalam setiap hubungan hukum dalam kehidupan masyarakat. Dalam berbagai hubungan hukum kebutuhan akan pembuktian tertulis berupa akta otentik makin meningkat sejalan dengan berkembangnya tuntutan akan kepastian hukum dalam berbagai hubungan ekonomi dan sosial, baik pada tingkat nasional, regional, maupun global. Melalui akta otentik yang menentukan secara jelas hak dan kewajiban, menjamin kepastian hukum, dan sekaligus diharapkan pula dapat menjadi jalan keluar pada saat terjadi sengketa.

Untuk memenuhi kebutuhan masyarakat akan akta otentik, negara memberikan kewenangan untuk membuat akta otentik kepada pejabat publik. Untuk akta otentik yang bersifat keperdataan dibuat oleh atau dihadapan Notaris untuk akta-akta umum, PPAT untuk akta-akta tanah tertentu dan Pejabat Lelang untuk akta-akta terkait penjualan di muka umum, sedangkan untuk kebutuhan akta otentik yang bersifat administratif seperti akta kelahiran, surat keterangan kematian dan lain-lain dibuat oleh Pejabat Publik dari unsur pemerintahan.

Lahirnya lembaga Notaris di Indonesia pada hakikatnya adalah untuk memberikan kepastian hukum serta perlindungan hukum bagi masyarakat melalui alat bukti berupa akta otentik yang dapat dibuat dihadapan Notaris. Berkaitan dengan hal ini, dalam perkembangannya banyak kasus yang berkaitan dengan jabatan Notaris, sehingga Notaris harus dapat mempertanggung jawabkan terhadap akta otentik yang dibuat, hal ini secara khusus banyak terjadi karena dipertanyakannya keaslian dari akta yang telah dibuat dihadapan Notaris. Kondisi tersebut melahirkan wacana mengenai penggunaan barcode dalam akta Notaris sebagai sarana pengaman untuk mengetahui keaslian produk Notaris tersebut.

Adanya wacana penggunaan barcode dalam Akta Notaris menimbulkan permasalahan karena Undang-Undang Nomor 30 Tahun 2004 Tentang Jabatan Notaris sebagaimana telah diubah dengan Undang-Undang Nomor 2 Tahun 2014 Tentang Perubahan Atas Undang-Undang Nomor 30 Tahun 2004 Tentang Jabatan Notaris (UUJN) tidak mengatur mengenai boleh atau tidaknya penggunaan barcode pada akta Notaris, baik pada minuta akta maupun salinan akta.

\section{Rumusan Masalah}

1) Apa fungsi barcode yang dilekatkan pada minuta akta dan salinan akta?

2) Apa implikasi hukum terhadap minuta akta dan salinan akta notaris yang diberikan barcode?

\section{Metode Penelitian}

Penelitian ini menggunakan metode penelitian hukum normatif yang dilakukan untuk mencari pemecahan masalah atas permasalahan hukum yang ada. Pendekatan penelitian yang digunakan adalah pendekatan undangundang (statute approach) dan pendekatan konseptual (conceptual approach).

\section{Pembahasan}

\section{Fungsi Penggunaan Barcode Pada Minuta Akta dan Salinan Akta}

Pada hakekatnya setiap orang berhak mendapatkan perlindungan dari hukum. Hampir seluruh hubungan hukum harus mendapat perlindungan dari hukum. Perlindungan hukum harus 
melihat tahapan yakni perlindungan hukum lahir dari suatu ketentuan hukum dan segala peraturan hukum yang diberikan oleh masyarakat yang pada dasarnya merupakan kesepakatan masyarakat tersebut untuk mengatur hubungan perilaku antara anggotaanggota masyarakat dan antara perseorangan dengan pemerintah yang dianggap mewakili kepentingan masyarakat.

Awal mula lahirnya teori perlindungan hukum bersumber dari teori hukum alam atau aliran hukum alam yang dikemukakan oleh Plato, Aristoteles yang menjelaskan bahwa hukum itu bersumber dari Tuhan yang bersifat universal dan abadi, serta antara hukum dan moral tidak boleh dipisahkan. Secara umum Plato dan Aristoteles memandang hukum dan moral adalah cerminan kehidupan manusia yang diwujudkan melalui hukum dan moral (Satjipto Rahardjo, 2000:52).

Perlindungan hukum dapat berarti perlindungan yang diberikan hukum terhadap sesuatu. Hukum sejatinya harus dapat memberikan perlindungan terhadap semua pihak sesuai dengan status hukumnya karena setiap orang memiliki kedudukan yang sama dihadapan hukum. Setiap aparat penegak hukum wajib menegakkan hukum dan dengan berfungsinya aturan hukum, maka secara tidak langsung pula hukum akan memberikan perlindungan terhadap setiap hubungan hukum atau segala aspek dalam kehidupan masyarakat yang diatur oleh hukum itu sendiri.

Menurut Sudikno Mertokusumo, yang dimaksud dengan hukum adalah kumpulan peraturan atau kaedah yang mempunyai isi yang bersifat umum dan normatif, umum karena berlaku bagi setiap orang dan normative karena menentukan apa yang seyogyanya dilakukan, apa yang tidak boleh dilakukan atau harus dilakukan serta menentukan bagaimana caranya melaksanakan kepatuhan pada kaedahkaedah (Sudikno Mertokusumo, 1991:38). Jadi perlindungan hukum adalah suatu perbuatan hal melindungi subjek - subjek hukum dengan peraturan perundang-undangan yang berlaku dan pelaksanaannya dapat dipaksakan dengan suatu sanksi.

Interaksi hubungan manusia yang satu dengan manusia yang lainnya membutuhkan suatu bingkai hukum yang mampu memberikan perlindungan hukum bagi yang terlibat di dalamnya. Dalam hubungan manusia yang dirupakan menjadi suatu bentuk perbuatan hukum dibutuhkan pula alat bukti yang mampu memberikan kepastian hukum, salah satunya melalui alat bukti tertulis berupa akta.

Akta adalah merupakan suatu tulisan yang memang dengan sengaja dibuat untuk dijadikan bukti tentang suatu peristiwa dan ditandatangani. Dengan demikian maka unsur-unsur yang penting untuk suatu akta ialah kesengajaan untuk menciptakan suatu bukti tertulis dan penandatanganan tulisan itu (R. Soebekti, 1996:25).

A.Pitlo, berpendapat bahwa : "Akta adalah suatu surat yang ditanda tangani, diperbuat untuk dipakai sebagai bukti, dan untuk dipergunakan oleh orang untuk keperluan siapa surat itu dibuat". Sedangkan menurut Sudikno Mertokusumo yang dimaksud Akta adalah surat yang diberi tanda tangan yang memuat peristiwa-peristiwa yang menjadi dasar dari suatu hak atau perikatan yang dibuat sejak semula dengan sengaja untuk pembuktian. Penandatanganan merupakan suatu hal yang terpenting dalam pembuatan suatu akta. Dengan menambahkan 
tandatangannya seseorang dianggap menanggung tentang kebenaran apa yang ditulis dalam akta tersebut atau bertanggungjawab tentang apa yang ditulis dalam akta itu (Ibid:26).

Lebih lanjut menurut Sudikno Mertokusumo, surat sebagai alat bukti tertulis dibagi menjadi dua yaitu surat yang merupakan akta dan surat-surat lainnya yang bukan akta, sedangkan akta sendiri dibagi lebih lanjut menjadi akta otentik dan akta di bawah tangan (Sudikno Mertokusumo, Loc Cit). Adapun akta yang dibuat di bawah tangan maupun akta otentik merupakan salah satu alat bukti surat yang digunakan dalam proses pembuktian di pengadilan.

Berdasarkan ketentuan Pasal 165 HIR (Pasal 285 RBg dan Pasal 1870 BW), maka akta otentik merupakan alat bukti yang sempurna bagi kedua belah pihak, ahli warisnya dan orang-orang yang mendapat hal dari padanya, yang berarti bahwa akta otentik itu masih dapat dilumpuhkan oleh bukti lawan. Sempurna dalam arti bahwa akta otentik tersebut sudah cukup untuk membuktikan sesuatu peristiwa atau hak tanpa perlu penambahan pembuktian dengan alat-alat bukti lain. Terhadap pihak ketiga, akta otentik itu merupakan alat bukti dengan kekuatan pembuktian bebas, yaitu penilaiannya diserahkan kepada pertimbangan hakim.

Akta otentik secara teoritis adalah surat atau akta yang sejak semula dengan sengaja secara resmi dibuat untuk pembuktian, dimana pembuktian itu dilakukan jikalau terjadi sengketa dikemudian hari. Apabila suatu akta merupakan akta otentik, maka akta tersebut akan mempunyai 3 (tiga) fungsi terhadap para pihak yang membuatnya yaitu (Salim H.S, 2006:43) :

1. Sebagai bukti bahwa para pihak yang bersangkutan telah mengadakan perjanjian tertentu;
2. Sebagai bukti bagi para pihak bahwa apa yang tertulis dalam perjanjian adalah menjadi tujuan dan keinginan para pihak;

3. Sebagai bukti kepada pihak ketiga bahwa pada tanggal tertentu kecuali jika ditentukan sebaliknya para pihak telah mengadakan perjanjian dan bahwa isi perjanjian adalah sesuai dengan kehendak para pihak.

Menurut K. Wantjik Saleh, berdasarkan Undang-Undang suatu akta resmi mempunyai kekuatan pembuktian yang sempurna (Volledig Bewijs), artinya apabila suatu pihak memajukan suatu akta resmi, hakim harus menerimanya dan menganggap bahwa apa yang dituliskan dalam akta itu sungguhsungguh telah terjadi, sehingga hakim tidak boleh memerintahkan penambahan pembuktian lagi (K. Wantjik Saleh, 1981:62).

Menurut GHS. Lumban Tobing perbedaan terbesar antara akta otentik dengan akta yang dibuat di bawah tangan antara lain (G.H.S Luman Tobing, 1979:54):

a. Akta otentik mempunyai tanggal yang pasti, sedang mengenai tanggal dari akta yang dibuat di bawah tangan tidak selalu demikian;

b. Grosse dari akta otentik dalam beberapa hal mempunyai kekuatan eksekutorial seperti putusan hakim, sedang akta yang dibuat di bawah tangan tidak pernah mempunyai kekuatan eksekutorial;

c. Kemungkinan hilangnya akta yang dibuat di bawah tangan lebih besar dibandingkan dengan akta otentik.

Pembuatan akta otentik ada yang diharuskan oleh peraturan perundangundangan dalam rangka kepastian, ketertiban dan perlindungan hukum. Pembuatan akta otentik di hadapan notaris bukan saja karena diharuskan oleh peraturan perundang-undangan, 
tetapi juga karena dikehendaki oleh pihak yang berkepentingan demi kepastian hak dan kewajiban para pihak yang berkepentingan sekaligus bagi masyarakat secara keseluruhan. Dalam menjalankan jabatannya sebagai seorang pejabat umum yang diberikan wewenang oleh Negara untuk membuat akta otentik, maka Notaris dalam melakukan pekerjaanya haruslah sesuai dengan koridor tugas dan tanggung jawab seperti yang telah dinyatakan dalam UUJN.

Jabatan Notaris mempunyai dua ciri dan sifat yang essential, ketidakmemihakkan dan kemandiriannya dalam memberikan bantuan kepada para kliennya. Adalah suatu credo, suatu keyakinan, bahwa kedua ciri tersebut melekat pada dan identik dengan perilaku pelaku jabatan ini (Herlien Budiono, 2015:281). Menurut Habib Adjie, meskipun secara administratif Notaris diangkat dan diberhentikan oleh pemerintah, tidak berarti Notaris menjadi subordinasi (bawahan) yang mengangkatnya pemerintah. Dengan demikian Notaris dalam menjalankan tugas jabatannya: a) Bersifat mandiri (autonomous); b) Tidak memihak siapapun (impartial); c) Tidak tergantung kepada siapapun (independent), yang berarti dalam menjalankan tugas jabatannya tidak dapat dicampuri oleh pihak yang mengangkatnya atau oleh pihak lain (Habib Adjie, 2008:16).

Kedudukan Notaris sebagai suatu jabatan yang terhormat dan memiliki peran sangat penting dalam masyarakat tentunya mengharuskan siapa yang memangku jabatan tersebut memiliki kualitas yang mumpuni baik secara keilmuan maupun kepemimpinan. Ilmu pengetahuan khususnya di bidang hukum harus benar-benar dipahami oleh Notaris secara mendalam. Hal tersebut tercermin dari salah satu syarat pengangkatan Notaris yang disebutkan dalam Pasal 3 huruf e UUJN adalah "Berijazah Sarjana Hukum dan lulus jenjang strata dua Kenotariatan".

Adanya kualifikasi khusus tentang pendidikan minimal bagi syarat pengangkatan Notaris seperti yang telah disebutkan diatas yaitu Sarjana Hukum dan jenjang strata dua kenotariatan yang lazim disebut dengan Magister Kenotariatan bukan tanpa alasan, hal tersebut ditujukan agar Notaris menjadi sosok yang mampu menyampaikan kebenaran dan memberikan keadilan bagi pihak yang membutuhkan jasanya, bukan sekedar memberikan kepastian hukum semata (Rusdianto Sesung, 2017). Tidak hanya sebatas itu, melalui akta otentik yang menjadi produk dari Notaris diharapkan mampu memberikan perlindungan hukum bagi para pihak yang menggunakan jasa Notaris.

Menurut Hatta Isnaini Wahyu Utomo, perkembangan jaman yang terus maju diiringi pula berbagai macam halhal baru baik yang bersifat positif maupun negatif. Semakin canggih teknologi membawa dampak bahwa kejahatan pada saat ini juga semakin canggih. Salah satu yang berkaitan dengan dunia Notaris adalah kejahatan berupa pemalsuan akta. Hal tersebut dapat berdampak membawa Notaris ke ranah hukum pidana, meskipun tidak jarang pula Notaris dinyatakan tidak terbukti bersalah oleh pengadilan (Hatta Isnaini Wahyu Utomo, 2018:13). Kondisi tersebut melahirkan pemikiran tentan penggunaan barcode pada minuta akta dan salinan akta Notaris. Didalam dunia notaris sendiri barcode bukan hal yang baru karena Kementerian Hukum Dan Hak Asasi Manusia telah menggunakan sistem barcode pada Surat Keputusan (SK) antara lain untuk SK Badan Hukum dan sertifikat fidusia. 
Barcode merupakan sebuah pola geometris yang umumnya memiliki bentuk vertikal. Fungsi dari barcode adalah untuk memindai dan melacak sebuah barang atau properti. Bentuk barcode biasanya berupa tanda misalnya simbol dan/atau angka yang biasanya dilekatkan ke produk. Produk yang ditandai barcode itu berasal dari sesuatu orang/ perusahaan yang mempunyai identitas. Biasanya dengan produk berupa barang dengan mengindentifikasi barcode dapat diketahui asal produk, produsen yang mengeluarkan, nomor seri (jika ada seri), kapan produk dibuat, daerah distribusi dan lain sebagainya yang kira-kira bermanfaat untuk produsen (pengeluar produk) ataupun user (pemakai). Untuk membaca barcode ada begitu banyak pilihan di pasaran dengan harga yang relatif murah mulai dari yang berbentuk pena (wand), slot, scanner, sampai ke CCD dan bahkan kita dapat membuatnya sendiri. Jenis barcode sangatlah banyak mulai dari yang tradisional yaitu 1 dimensi sampai dengan barcode yang multi dimensi, dalam artikel ini akan dibahas barcode 1 dimensi dan dibatasi pada jenis-jenis yang populer digunakan tetapi dapat memberi pengertian dan gambaran yang jelas mengenai barcode (http://www.innovativeelectronics.com/fil es/files/37369_15a345_49c889.pdf, 2018).

Menurut Stephen A. Brown, yang dimaksud barcode adalah suatu kumpulan data optik yang dibaca mesin. Sebenarnya, kode batang ini mengumpulkan data dalam lebar (garis) dan spasi garis paralel dan dapat disebut sebagai kode batang atau simbologi linear atau 1D (1 dimensi). Tetapi juga memiliki bentuk persegi, titik, heksagon dan bentuk geometri lainnya di dalam gambar yang disebut kode matriks atau simbologi 2D (2 dimensi). Selain tak ada garis, sistem 2D sering juga disebut sebagai kode batang. Penggunaan awal kode batang adalah untuk mengotomatiskan sistem pemeriksaan di swalayan, tugas dimana mereka semua menjadi universal saat ini. Penggunaannya telah menyebar ke berbagai kegunaan lain juga, tugas yang secara umum disebut sebagai Auto ID Data Capture (AIDC) (Stephen A. Brown, 2012:3).

Dalam Penjelasan Pasal 34 Peraturan Pemerintah Nomor 82 Tahun 2012 tentang Penyelenggaraan Sistem dan Transaksi Elektronik barcode dimasukan kedalam kategori data elektronik yang dibuat sendiri oleh Penyelenggara Sistem Elektronik atau Penyelenggara Agen Elektronik. Dalam Peraturan Menteri Perdagangan Nomor 24/M-DAG/PER/4/2016 tentang Standarisasi Bidang Perdagangan, barcode dapat kedalam 2 (dua) jenis sistem kode, yaitu Nomor Registrasi Produk (NRP) dan Nomor Pendaftaran Barang (NPB).

Menurut Habib Adjie, berkaitan dengan produk notaris yaitu akta otentik, sejauh mana diperlukan sebagai pengamannya menggunakan barcode seharusnya sudah dapat diterapkan, tapi sifatnya mungkin belum untuk semua jenis akta akta notaris, barcode dapat digunakan pada minuta dan salinan akta notaris yang memiliki bobot hukumnya dan nilai ekonominya tinggi, sehingga seimbang dengan mahalnya teknologi yang terdapat dalam barcode tersebut. Tujuan penggunaan barcode yang semula diterapkan dalam dunia perdagangan barang, saat ini juga sudah bisa dicoba untuk digunakan sebagai pengaman pada minuta dan salina akta notaris, yang mana memang tujuan dibuatnya akta notaris adalah agar terciptanya kepastian hukum dan perlindungan hukum terhadap kepentingan para pihak yang dituangkan 
kedalam akta notaris (Habib Adjie, 2018:4).

Fungsi barcode bagi Notaris adalah sebagai identitas untuk mengetahui bahwa akta tersebut memang benarbenar akta yang dibuat oleh Notaris yang bersangkutan. Apabila suatu saat akta tersebut diperlukan, maka para pihak atau Notaris lain yang mempergunakan akta tersebut tentunya dapat melakukan pengecekan untuk memastikan bahwa betul akta itu akta yang dibuat rekan Notaris.

Sistem barcode dapat diterakan pada Minuta dan Salinan Akta sebagai pengaman. Tujuannya adalah sebagai penanda keaslian dari Minuta dan Salinan Akta, dan juga sebagai pengaman bahwa benar produk hukum tersebut adalah produk yang dibuat oleh dan/atau dihadapan Notaris yang bersangkutan dan berisi data tertentu yang sudah disimpan dalam sistemnya itu. Tujuan dibuatnya akta notaris adalah agar terciptanya kepastian hukum dan perlindungan hukum terhadap kepentingan para pihak yang dituangkan kedalam akta notaris. Tujuan tersebut dapat semakin diperkuat dengan penggunaan barcode pada minuta dan salinan akta Notaris.

\section{Implikasi Hukum Terhadap Minuta Akta Dan Salinan Akta Notaris Yang Diberikan Barcode}

Adanya kepastian hukum merupakan harapan bagi pencari keadilan karena dengan adanya kepastian hukum masyarakat akan tahu kejelasan akan hak dan kewajiban menurut hukum. Tanpa ada kepastian hukum maka orang akan tidak tahu apa yang harus diperbuat, tidak mengetahui perbuatanya benar atau salah, dilarang atau tidak dilarang oleh hukum.

Kepastian hukum ini dapat diwujudkan melalui penormaan yang baik dan jelas dalam suatu undangundang dan akan jelas pulah penerapanya, dengan kata lain kepastian hukum itu berarti tepat hukumnya, subjeknya dan objeknya serta ancaman hukumanya. Akan tetapi kepastian hukum mungkin sebaiknya tidak dianggap sebagai elemen yang mutlak ada setiap saat, tapi sarana yang digunakan sesuai dengan situasi dan kondisi dengan memperhatikan asas manfaat dan efisiensi.

Kepastian hukum secara normatif adalah suatu peraturan dibuat dan diundangkan secara pasti digunakan untuk mengatur secara jelas dan logis suatu hal. Jelas tidak menimbulkan keragu-raguan dan logis dalam artian bahwa ia menjadi suatu sistem norma dengan norma lain sehingga tidak berbenturan atau menimbulkan konflik norma, kekosongan norma ataupun adanya kekaburan norma.

Menurut Gustav Radbruch hukum memiliki tujuan yang berorientasi pada tiga hal yaitu kepastian hukum, keadilan dan daya guna (Gustav Radbruch dalam O. Notohamidjojo, 2011:33). Kepastian kata dasarnya adalah pasti, yang memiliki arti suatu hal yang sudah tentu, sudah tetap dan tidak boleh tidak. Gustav Radbruch seperti yang dikutip oleh Theo Huijber mengenai kepastian hukum mengemukakan bahwa pengertian hukum dapat dibedakan menjadi tiga aspek yang ketiga-tiganya diperlukan untuk sampai pada pengertian hukum yang memadai. Aspek pertama adalah keadilan dalam arti yang sempit. Keadilan ini berarti kesamaan hak untuk semua orang di depan pengadilan. Aspek yang kedua adalah tujuan keadilan atau finalitas dan aspek yang ketiga adalah kepastian hukum atau legalitas (Gustav Radbruch dalam Theo Huijbers, 2007:163). 
Tugas jabatan yang dijalankan oleh para Notaris bukan sekedar pekerjaan yang diamanatkan oleh undang-undang semata, namun sekaligus menjalankan suatu fungsi sosial yang sangat penting yaitu bertanggung jawab untuk melaksanakan kepercayaan yang diberikan masyarakat umum yang dilayaninya, Notaris mempunyai kedudukan dan peran yang sangat penting dalam kehidupan berbangsa dan bernegara, karena mempunyai kewenangan atau authority yang telah ditentukan dalam peraturan perundangundangan. Kewenangan notaris, yang dalam bahasa Inggrisnya disebut dengan the notary of authority, sedangkan dalam bahasa Belanda disebut dengan de notaris autoriteit, yaitu berkaitan dengan kekuasaan yang melekat pada diri seorang notaris. Ada dua suku kata yang terkandung dalam kewenangan notaris, yang meliputi: (1) kewenangan; dan (2) notaris (Salim H.S, 2015:47).

Ada dua unsur yang terkandung dalam konsep kewenangan yang disajikan oleh H.D. Stoud, yaitu: (1) adanya aturan-aturan hukum; dan (2) sifat hubungan hukum. Sebelum kewenangan itu dilimpahkan kepada institusi yang melaksanakannya, maka terlebih dahulu harus ditentukan dalam peraturan perundang-undangan, apakah dalam bentuk undang-undang, peraturan pemerintah maupun aturan yang lebih rendah tingkatannya (H.D Stoud dalam Salim H.S., Ibid:48).

Sifat hubungan hukum adalah sifat yang berkaitan dan mempunyai sangkut paut atau ikatan atau pertalian atau berkaitan dengan hukum. Hubungan hukumnya ada yang bersifat publik dan privat. Sementara itu, notaris dikonstruksikan sebagai pejabat umum. Pejabat merupakan orang yang melakukan pekerjaan atau tugas untuk melayani kepentingan masyarakat secara keseluruhan.

Dari uraian di atas, dapat disajikan pengertian kewenangan notaris. Kewenangan notaris dikonstruksikan sebagai : "Kekuasaan yang diberikan oleh undang-undang kepada notaris untuk membuat akta autentik maupun kekuasaan lainnya". Unsur-unsur yang terkandung dalam konsep kewenangan notaris, yang meliputi: (1) adanya kekuasaan; (2) ditentukan oleh undangundang; dan (3) adanya objek (Ibid:49). Kekuasaan diartikan sebagai kemampuan dari notaris untuk melaksanakan jabatannya. Kewenangan notaris dibagi menjadi dua macam, yaitu: (1) kewenangan membuat akta autentik; dan (2) kewenangan lainnya yang telah ditentukan dalam peraturan perundangundangan.

Dalam menjalankan tugas dari jabatannya Notaris mempunyai tugas untuk membuat akta otentik bagi masyarakat yang membutuhkan, akta otentik yang dibuat oleh Notaris adalah merupakan suatu pembuktian yang sempurna yang melahirkan suatu kepastian hukum apabila sewaktu-waktu terjadi perselisihan diantara para pihak yang membuat atau membutuhkan akta tersebut.

Pembuatan akta otentik sebagian besar diawali oleh kehendak pihak-pihak yang berkepentingan untuk pembuatan akta tersebut dan kemudian datang menghadap kepada Notaris dengan tujuan membuat suatu alat bukti yang sah menurut Undang-Undang. Di hadapan Notaris para penghadap menjelaskan maksud dan tujuan mereka serta menjelaskan apa saja yang dikehendaki dan tugas dari Notaris adalah memformulasikan kehendak para pihak kedalam sebuah bentuk akta otentik. 
Setelah kehendak dari para penghadap tersebut telah tertuang ke dalam akta maka kemudian notaris membacakan akta tersebut dan apabila para penghadap telah setuju dan memahami isi yang telah tertulis dalam akta tersebut maka segera para penghadap, saksi-saksi dan Notaris menandatangani akta tersebut. Ketentuan tersebut berdasarkan Pasal 44 ayat (1) UUJN yang menyebutkan : "Segera setelah Akta dibacakan, Akta tersebut ditandatangani oleh setiap penghadap, saksi, dan Notaris, kecuali apabila ada penghadap yang tidak dapat membubuhkan tanda tangan dengan menyebutkan alasannya."

Setelah akta tersebut ditandatangani dengan sempurna maka akta tersebut telah menjadi minuta akta. Dalam Pasal 1 angka 8 UUJN disebutkan bahwa Minuta Akta adalah asli Akta yang mencantumkan tanda tangan para penghadap, saksi dan Notaris, yang disimpan sebagai bagian dari Protokol Notaris. Dari minuta akta tersebut dibuatlah salinan akta yang diberikan kepada para pihak. Pasal 1 angka 9 UUJN mendefinisikan salinan Akta adalah salinan kata demi kata dari seluruh Akta dan pada bagian bawah salinan Akta tercantum frasa "diberikan sebagai SALINAN yang sama bunyinya".

Dari rumusan yang telah tertuang di dalam Pasal 1868 BW dapat diuraikan bahwa syarat agar dapat disebut sebagai akta otentik adalah : 1) Dibuat dalam bentuk yang telah ditentukan oleh Undang-Undang; 2) Dibuat oleh dan dihadapan pejabat yang berwenang; 3) Dibuat di tempat yang wilayahnya masih di dalam kewenangan pejabat yang membuat akta tersebut. Ketiga syarat yang disebutkan untuk suatu akta agar dapat dikualifikasikan sebagai akta otentik sebagaimana tersebut diatas berlaku secara akumulatif, dalam arti ketiga syarat harus dipenuhi semuanya dan jika tidak dipenuhi maka akta hanya mempunyai kekuatan pembuktian sebagai akta di bawah tangan saja.

Mengenai ketentuan "bentuk yang telah ditentukan Undang-Undang" diatur secara lex specialis dalam Pasal 38 sampai dengan Pasal 44 UUJN. Jika semua ketentuan yang terdapat dalam Pasal-Pasal dalam UUJN tersebut diatas telah terpenuhi, maka dapat dipastikan predikat akta otentik sebagaimana terdapat dalam Pasal 1868 BW dan kekuatan pembuktian yang sempurna sebagaimana terdapat dalam Pasal 1870 BW dapat terpenuhi, sekalipun tidak menggunakan barcode. Artinya apa yang diharapkan dari sebuah akta otentik yang dibuat oleh dan/atau dihadapan notaris yaitu Perlindungan Hukum dan Kepastian Hukum telah terpenuhi. Sebaliknya, jika Minuta dan Salinan Akta Notaris menggunakan barcode tetapi tidak terpenuhi persyaratan-persyaratan dalam pembuatan akta sebagaimana dimaksud diatas, maka Minuta dan Salinan Akta tersebut tidak akan dapat di sebut sebagai Akta Otentik yang memiliki kekuatan pembuktian yang sempurna.

\section{Kesimpulan}

Tujuan dibuatnya akta notaris adalah agar terciptanya kepastian hukum dan perlindungan hukum terhadap kepentingan para pihak yang dituangkan kedalam akta notaris. Dari adanyan tujuan tersebut lahir suatu penemuan hukum mengenai penggunaan barcode dalam minuta dan salinan akta Notaris. Fungsi penggunaan barcode pada Minuta dan Salinan Akta adalah sebagai pengaman bahwa benar produk hukum tersebut adalah produk yang dibuat oleh dan/atau dihadapan Notaris yang bersangkutan dan berisi data tertentu yang sudah disimpan dalam sistemnya itu. 
Akta Notaris dikualifikasikan sebagai akta otentik apabila aspek formal pembuatannya yang telah ditentukan dalam UUJN terpenuhi seluruhnya. Akta Notaris yang menggunakan barcode pada minuta dan salinan akta merupakan akta otentik dan mempunyai kekuatan pembuktian yang sempurna selama aspek formal dalam pembuatan akta terpenuhi.

\section{Saran}

Notaris diharapkan menggunakan barcode pada minuta dan salinan akta sebagai sarana pengaman akta agar mampu memberikan perlindungan hukum bagi para pihak yang membuat akta dihadapannya. Agar tidak terjadi kerancuan mengenai keabsahan penggunaan barcode diperlukan adanya regulasi yang tegas mengatur penggunaan barcode pada minuta dan salinan akta

\section{Daftar Pustaka}

Buku-Buku

Darwan Prinst, Hukum Acara Pidana Dalam Praktik, Djambatan, Jakarta, 1998

G.H.S. Lumban Tobing, Peraturan Jabatan Notaris, Kelompok Belajar Esa, Jakarta, 1979

Habib Adjie, Hukum Notaris Indonesia, Refika Aditama, Bandung, 2008

Herlien Budiono, Kumpulan Tulisan Hukum Perdata Di Bidang Kenotariatan, Citra Aditya Bakti, Bandung, 2015

K. Wantjik Saleh, Hukum Acara Perdata $(\mathrm{RBg} / \mathrm{HIR})$, Ghalia Indonesia, Jakarta, 1981

O. Notohamidjojo, Soal-Soal Pokok Filsafat Hukum, Griya Media, Salatiga, 2011

R. Subekti, Hukum Pembuktian, Pradnya Paramita, Jakarta, 2001
R.Soebekti, Hukum Perjanjian, Intermasa, Jakarta, 1996

Salim H.S., Hukum Kontrak-Teori dan Teknik Penyusunan Kontrak, Sinar Grafika, Jakarta, 2006

Salim H.S., Teknik Pembuatan Akta Satu (Konsep Teoritis, Kewenangan Notaris, Bentuk dan Minuta Akta), RajaGrafindo Persada, Jakarta, 2015

Satijipto Rahardjo, Ilmu Hukum, Citra Aditya Bakti, Bandung, 2000

Stephen A. Brown, Revolution at the Checkout Counter: The Explosion of the Bar Code, Harvard Univ Press, Harvard, n.y., n.p.

Sudikno Mertokusumo, Hukum Acara Perdata Indonesia, Liberty, Yogyakarta, 1999, h

Sudikno Mertokusumo, Mengenal Hukum : Suatu Pengantar, Liberty, Yogyakarta, 1991

Theo Huijbers, Filsafat Hukum Dalam Lintas Sejarah, Kanisius, Yogyakarta, 2007

Yudha Yudhanto, "Sejarah Tekmologi Barcode", Makalah, Komunitas eLearning IlmuKomputer, 2012

\section{Jurnal dan Makalah}

Habib Adjie, "Barcode Pengaman Hakiki Akta Notaris" Makalah, disampaikan pada Seminar Pembuatan Barcode Pada Minuta Dan Salinan Akta, Universitas Narotama, Surabaya, 24 Februari 2018

Hatta Isnaini Wahyu Utomo, "Pelaksanaan Tugas Jabatan Notaris : Bahan Diskusi Dalam Persiapan Menghadapi Ujian Kode Etik Notaris", Makalah, disampaikan pada acara Belajar Bareng Alumni, Universitas Narotama Surabaya, Februari 2018 Neriana, "Kekuatan Pembuktian Akta Dibawah Tangan Perjanjian Jual 
Beli Dihubungkan Dengan Kewenangan Notaris Dalam Pasal 15 Ayat (2) Undang-Undang Nomor 2 Tahun 2014 Tentang Perubahan Atas Undang-Undang Nomor 30 Tahun 2004 Tentang Jabatan Notaris", Jurnal JOM, Volume 2 Nomor 2, Oktober 2015

\section{Internet}

http://www.innovativeelectronics.com/ files/files/37369_15a345_49c889. pdf diakses Senin, 27 Maret 2018, Pukul 21.00 WIB

Rusdianto Sesung, "Sebagai Salah Satu Profesi Hukum, Benarkah Notaris Hanya Untuk Menjamin Kepastian Hukum Semata?", www. notary.my.id, diakses pada hari Sabtu, 15 April 2018, pukul 01.28 WIB 